\title{
Training the next generation of Africa's doctors: why medical schools should embrace the team-based learning pedagogy
}

\author{
Charles Okot Odongo ${ }^{1 *}$ id and Kristina Talbert-Slagle ${ }^{2}$
}

\begin{abstract}
Background: As far back as 1995, the Cape Town Declaration on training Africa's future doctor recognized the need for medical schools to adopt active-learning strategies in order to nurture holistic development of the doctor. However, medical education in Africa remains largely stuck with traditional pedagogies that emphasize the 'hard skills' such as knowledge and clinical acumen while doing little to develop 'soft skills' such as effective communication, teamwork, critical thinking or life-long learning skills.

Body of abstract: By reviewing literature on Africa's epidemiologic and demographic transitions, we establish the need for increasing the output of well-trained doctors in order to match the continent's complex current and future healthcare needs. Challenges that bedevil African medical education such as outdated curricula, limited educational infrastructure and chronic resource constraints are presented and discussed. Furthermore, increased student enrollments, a trend observed at many schools, coupled with chronic faculty shortages have inadvertently presented specific barriers against the success of small-group active-learning strategies such as Problem-Based and Case-Based Learning. We argue that Team-Based Learning (TBL) offers a robust alternative for delivering holistic medical education in the current setting. TBL is instructor-driven and embodies key attributes that foster development of both 'hard' and 'soft' skills. We elaborate on advantages that TBL is likely to bring to the African medical education landscape, including increased learner enthusiasm and creativity, accountability, peer mentorship, deep learning and better knowledge retention. As with all new pedagogical methods, challenges anticipated during initial implementation of TBL are discussed followed by the limited pilot experiences with TBL in Africa.
\end{abstract}

Conclusion: For its ability to enable a student-centered, active learning experience delivered at minimum cost, we encourage individual instructors and African medical schools at large, to adopt TBL as a complementary strategy towards realizing the goal of training Africa's fit-for-purpose doctor.

Keywords: Team-based learning, Africa, Medical schools, Doctors, Pedagogy

\section{Background}

Over the years, medical schools globally have experimented with new curricula and different pedagogical formats aimed at improving the learning process $[1,2]$. In many settings, implementation of these innovations has not been without challenges, often resulting in substantial modifications or

\footnotetext{
* Correspondence: codongo76@gmail.com

${ }^{1}$ Department of Pharmacology \& Therapeutics, Faculty of Medicine, Gulu University, P.O. Box 166, Gulu, Uganda

Full list of author information is available at the end of the article
}

abandonment [2-4]. In some instances, these modifications have appeared to erode key philosophical tenets on which such innovations are premised, and possibly undermining learning outcomes [5, 6]. From its inception in the 1960s, problem-based learning (PBL), arguably the most widely experimented curriculum innovation, has generated plenty of controversy and debate [5-12]. In Africa and probably elsewhere, experiments with PBL in medical education have exposed systemic weaknesses that call into question the sustainability and success of similar innovations going

(c) The Author(s). 2019 Open Access This article is distributed under the terms of the Creative Commons Attribution 4.0 International License (http://creativecommons.org/licenses/by/4.0/), which permits unrestricted use, distribution, and reproduction in any medium, provided you give appropriate credit to the original author(s) and the source, provide a link to the Creative Commons license, and indicate if changes were made. The Creative Commons Public Domain Dedication waiver (http://creativecommons.org/publicdomain/zero/1.0/) applies to the data made available in this article, unless otherwise stated. 
forward $[7,13]$. Moreover, resources at many African medical schools are currently outstripped by rising student enrolments [14], a trend likely to compromise educational standards [15]. Thus, medical education in Africa is at a crossroad: in need of reforms that not only improve educational standards but also remain responsive to the continent's unique challenges and healthcare aspirations [16]. Mindful of lessons from previous experiences with novel pedagogies in Africa [7, 13], this article attempts to vouch for Team-Based Learning (TBL), a form of cooperative learning that is relatively new to medical education [17]. To build our case, information from a wide range of publications on current pedagogical strategies as well as medical education challenges, particularly in Africa were reviewed.

Using Africa's disease and demographic transition patterns, we justify its physician competency requirements and contrast these with current training experiences at its medical schools. The TBL pedagogical approach is then described showing how it instills core knowledge and skills attributes required to equip Africa's future doctors with the right competencies for effective practice. We proceed to elaborate how-with considerable parsimonyTBL mitigates the major challenges bedeviling reforms in African medical education. This is followed by examination of bottlenecks anticipated during initial implementation of TBL, together with a review of the limited African pilot experiences.

\section{Main text}

\section{Disease burden and demographic transitions in Africa}

Africa is disproportionately burdened by poverty and disease, a situation compounded by its low level of human resources for health. With an estimated $29 \%$ of the global disease burden in 2017 [18], Africa has 3.5\% of the global healthcare workforce of which only $1.7 \%$ are doctors [19]. At an average of 4.7 children per woman and a population growth rate of $2.7 \%$, Africa's statistics are the highest globally [20], projecting enormous healthcare needs. Since 1990, life expectancy in Africa has risen steadily - from an average of 49.7 to 60.7 years in 2017 [21]. Despite this improvement, infectious diseases continue to burden millions, coupled with a rising burden of non-communicable diseases such as cancers, diabetes, and cardiovascular diseases [18]. Therefore, Africa's dual disease epidemic will increasingly require healthcare providers with additional competencies. In recognition of this crisis, health planners have focused on increasing human resources for health [22, 23]. Here, training doctors has been particularly prioritized, not because they will meet the vast projected healthcare needs of the continent, but in the belief that no health system can function optimally without an adequate number of well-trained doctors to provide leadership, mentorship and effective clinical care [22].

\section{Skills requirement for the next generation of Africa's doctors}

Gone are the days when a doctor sat in the office and dispensed prescriptions with the support of one or two nurses. Doctors are increasingly practicing in teams along with a range of allied and interprofessional scientists. In large referral settings, doctors with varied expertise work collaboratively to deliver high-end interventional care. As heads of clinical teams, doctors are teachers, supervisors, mentors and role models to their subordinates. All these responsibilities require healthy and strong interpersonal relationships. During clinical care, doctor-patient communication needs to be compassionate yet truthful and unambiguous. Very intriguing perhaps, is a new breed of patients who increasingly indulge the web prior to seeking consultation [16], leading to uncomfortable doctor-patient encounters that call for a high level of emotional intelligence. Outside clinical care, doctors serve in managerial positions at all levels of healthcare. As prominent members and opinion leaders, society looks up to them for guidance. Clearly, beyond the 'hard' skills, effective delivery on the above mandates require an additional set of skills such as effective communication, compassion, critical thinking and collaboration. Furthermore, doctors require independent learning skills so as to secure their positions as life-long learners capable of keeping pace with new information relevant to their roles. However, until recently, curricula and pedagogical strategies in many African medical schools had barely changed, remaining focused on the transfer of 'hard' skills with little regard for 'soft' skills [16, 24]. More challenging perhaps, is the fact that soft skills cannot be transferred through instructorcentered, passive learning strategies; rather, they are nurtured through carefully designed pedagogies that afford learners the opportunity to hone these skills through mentored peer interaction. For instance, it is now known that didactic lectures, however eloquent, are less effective for developing problem-solving, critical thinking or independent learning skills [25]. For this reason, regulatory authorities globally are increasingly encouraging the adoption of student-centered active learning strategies in medical education [25-29]. As far back as 1995, the Cape Town Declaration on training Africa's future doctor recognized the need for medical schools to adopt active-learning strategies [30]. However, reports suggest that sustainable implementation of this recommendation has proved elusive $[14,16,24,31]$.

\section{Medical education challenges in Africa}

The academic environment at most African schools is such that what is termed 'success' is typically achieved through individual effort, in competition rather than collaboration with other learners. As most faculty lack formal pedagogical training $[16,24]$, teaching is mainly 
done using traditional instructor-centered strategies which more often than not promote learner dependency [14]. Until recently, curricula were generally outdated and in need of reform, yet a significant section of faculty continuously struggle with change initiatives [7, 24]. Despite the availability of rich online resources, the textbook and lecture notes still predominate, in part due to challenges with internet access [31]. Class time is disproportionately didactic, a model premised on the assumption that attendance translates into listening, understanding and knowledge retention. Preclinical students are expected to memorize large amounts of information, which they begin to apply later during clerkship. Academic progress is based primarily on students' ability to memorize facts, with little credit devoted to other skills. This paradigm continues despite the wellknown folly with memory-driven learning - that infrequently used knowledge is quickly forgotten [32,33]. Moreover, the rate at which medical knowledge is growing is now faster than anyone can comprehend, let alone learn at school. Amidst all this, students lack guidance on effective learning skills, despite increased scientific understanding on the neurobiology of learning [34, 35]. It is no wonder that many students feel overwhelmed by the sheer volume of content to master, a phenomenon that contributes to academic stress [36, 37]. Whereas medical education generally requires considerable personal effort and sacrifice, addressing the above structural challenges in African medical education would significantly enhance learning.

In Africa, medical education is predominantly a preserve of national governments whose competing priorities leave training institutions perennially underfunded [31]. Faculty recruitment and retention remain challenging owing to low public-sector salaries [14]. This situation is compounded by the rising trend in student enrollments that inevitably increases workload for the few faculty [31]. Students, on their part, face numerous challenges, some of which include inadequate learning infrastructure. For instance, Chen et al., highlight space shortages that frustrate students' efforts to meet for group discussions outside class [14]. Thus, without creative reforms, current challenges are counterproductive to the continent's aspiration to increase its number of doctors. On a positive note, the teaching and learning environment in some schools has registered modest improvement through the MEPI initiative [38]. More enduring, perhaps, will be the establishment of full-time medical education departments within schools to champion future reforms [39]. Acknowledging that resource constraints will probably persist for some years to come, medical educators need to embrace innovative pedagogies capable of delivering Africa's ideal doctor [30]. For its ability to optimize learning and enable efficient resource utilization, we posit that TBL is one such strategy that is increasingly gaining favor among medical educators globally $[17,40]$.

\section{What is team-based Learning?}

TBL is a form of cooperative learning where students are strategically organized into permanent study groups within a single classroom setting where the instructor creates, initiates, and directs all learning activities. The class is operated on 7 core educational principles designed to maximize student preparation and participation while fostering high levels of performance and accountability. Table 1 shows how these principles positively affect learner engagement with course content and peers. Students master content through a three-phase process as follows: Phase 1: pre-class preparation, in which learners consume assigned materials (readings, videos, dissection etc.). Phase 2: readiness assurance to apply new knowledge, achieved when all learners initially take a readiness test individually, followed by retake of the exact same test as a group, and coming to consensus on group answers to each question. This is followed by an instructor-led class debriefing, where groups have the opportunity to make appeals as long as they can advance valid arguments to support their answers. The instructor may also give a short and usually focused lecture, aimed at clarifying misconceptions that become apparent during the debriefing process. In Phase 3, learners have the opportunity to apply new knowledge through group problem-solving using assignments that simulate reallife and often involve complex or ambiguous scenarios. This stage is open-book (or open internet) since it is intended to stimulate guided knowledge acquisition and deeper learning. Groups are given time to confer, after which they make specific choice answers, to be simultaneously reported across the class. TBL assignments should consist of knowledge-application scenarios with potential to generate controversy. Only then can vibrant discussions and deeper learner engagement with content occur [42]. This is particularly true when groups eventually morph into self-managed and highly motivated learning teams capable of using their collective brain power to propose practical solutions to real-life problems [43]. TBL can be applied to teaching single topics or entire courses in higher education [40] and is suitable for both undergraduate and graduate level education [17, 40].

\section{Team-based Learning brings unique advantages to Africa's medical education landscape}

TBL is an instructor-led pedagogy that stimulates deductive learning within interactive small groups. In contrast to didactic learning strategies, where knowledge-acquisition is largely passive, TBL's in-class assignments ensure that very early on, learners develop a clear sense of how new knowledge may be applied in real-life. The instructor's role shifts from knowledge presenter to that of content preparation and moderator of the learning process. Learners are challenged to apply new knowledge in an 
Table 1 Core design elements of Team-Based Learning showing their effects on learner engagement with content and peers

\begin{tabular}{|c|c|c|c|}
\hline $\begin{array}{l}\text { Core design } \\
\text { element }\end{array}$ & Rationale/TBL principle & $\begin{array}{l}\text { Effect on learner engagement } \\
\text { with content }\end{array}$ & $\begin{array}{l}\text { Effect on learner } \\
\text { engagement with peers }\end{array}$ \\
\hline $\begin{array}{l}\text { 1. Judicious team } \\
\text { formation performed } \\
\text { by instructor }\end{array}$ & $\begin{array}{l}\text { Optimal team size and intellectual } \\
\text { resources (brain power) to be distributed } \\
\text { equally across teams. This does not } \\
\text { typically occur when learners are } \\
\text { allowed to form their own teams. }\end{array}$ & $\begin{array}{l}\text { Teams with too few learners (e.g. less } \\
\text { than 5) lack sufficient 'intellectual assets' } \\
\text { to tackle complex problems; too many } \\
\text { learners (e.g. more than 8) permits 'social } \\
\text { loafing' }\end{array}$ & $\begin{array}{l}\text { Team motivation to work together } \\
\text { increases when learners believe their } \\
\text { collective brain power matches that of } \\
\text { other teams }\end{array}$ \\
\hline $\begin{array}{l}\text { 2. Readiness } \\
\text { Assurance }\end{array}$ & $\begin{array}{l}\text { Allows the instructor and team } \\
\text { members to verify that all learners } \\
\text { are prepared to apply course concepts } \\
\text { to solve real-world, or complex tasks. }\end{array}$ & $\begin{array}{l}\text { Individual and team accountability } \\
\text { motivates learners to prepare by } \\
\text { acquiring background knowledge } \\
\text { before coming to class }\end{array}$ & $\begin{array}{l}\text { During group discussions, learners teach } \\
\text { each other, often using language that is } \\
\text { more familiar than that of the instructor }\end{array}$ \\
\hline $\begin{array}{l}\text { 3. Immediate } \\
\text { feedback }\end{array}$ & $\begin{array}{l}\text { Immediate feedback enhances both } \\
\text { individual learning and team } \\
\text { communication processes by allowing } \\
\text { teams to constantly assess the } \\
\text { effectiveness of their problem-solving } \\
\text { and communication strategies. }\end{array}$ & $\begin{array}{l}\text { Obtaining answers to questions } \\
\text { following the group test allows } \\
\text { individual misconceptions to be } \\
\text { clarified before they are entrenched }\end{array}$ & $\begin{array}{l}\text { Reinforces to team members the value } \\
\text { of collaboration. Also provides a } \\
\text { disincentive for poor team } \\
\text { communication behavior (e.g. poor } \\
\text { listening or overassertiveness) }\end{array}$ \\
\hline $\begin{array}{l}\text { 4. Sequencing of } \\
\text { in-class problem } \\
\text { solving }\end{array}$ & $\begin{array}{l}\text { Proper sequencing of activities- i.e. } \\
\text { intrateam followed by interteam } \\
\text { activities; enables learners to deepen } \\
\text { their level of thinking and can positively } \\
\text { affect the team development process }\end{array}$ & $\begin{array}{l}\text { Multiple opportunities to discuss and } \\
\text { apply knowledge to solve a problem } \\
\text { fosters greater depth of engagement } \\
\text { with course concepts and promotes } \\
\text { long-term knowledge retention }{ }^{46}\end{array}$ & $\begin{array}{l}\text { Interteam discussions solidify group } \\
\text { identity and cohesiveness. Teams want } \\
\text { to use their intrateam discussion time } \\
\text { effectively to avoid embarrassment } \\
\text { during interteam discussions }\end{array}$ \\
\hline 5. The four Ss & $\begin{array}{l}\text { Attention to the } 4 \mathrm{~S} \text { structure (i.e. } \\
\text { significant problem, same problem, } \\
\text { specific choice, simultaneous reporting) } \\
\text { fosters individual and team motivation, } \\
\text { a common frame of reference, critical } \\
\text { thinking and conceptual depth, and } \\
\text { vigor during whole class discussions }\end{array}$ & $\begin{array}{l}\text { A significant problem with real-life } \\
\text { relevance increases interest during team } \\
\text { discussions. Same problem for all teams } \\
\text { increases interest during interteam } \\
\text { discussions. The requirement to make } \\
\text { a specific choice fosters conceptual } \\
\text { depth in intra- and interteam } \\
\text { discussions. }\end{array}$ & $\begin{array}{l}\text { Simultaneous reporting of specific } \\
\text { choice enhances recognition of } \\
\text { controversy across teams. Constructive } \\
\text { controversy across teams motivates } \\
\text { collaboration within teams to defend } \\
\text { points of view }{ }^{41}\end{array}$ \\
\hline 6. Incentive structure & $\begin{array}{l}\text { As in any teaching endeavor, the } \\
\text { incentive structure has powerful effects } \\
\text { on the achievement of course goals }\end{array}$ & $\begin{array}{l}\text { Grading individual performance } \\
\text { motivates out-of-class preparation }\end{array}$ & $\begin{array}{l}\text { Grading team performance provides a } \\
\text { clear incentive to maximize collaboration }\end{array}$ \\
\hline 7. Peer evaluation & $\begin{array}{l}\text { This is especially critical in a longitudinal } \\
\text { TBL curriculum. Feedback from peers } \\
\text { may have effects that other forms of } \\
\text { feedback may not because peers have } \\
\text { a unique relationship with each other } \\
\text { as learners }\end{array}$ & $\begin{array}{l}\text { The possibility of a negative review from } \\
\text { peers motivates learners to prepare for } \\
\text { and participate in class. Peer feedback } \\
\text { also shapes specific learner behavior } \\
\text { such as over assertiveness and } \\
\text { collaboration }\end{array}$ & $\begin{array}{l}\text { Promotes individual learners' } \\
\text { accountability to the team. It also } \\
\text { reinforces the importance of every } \\
\text { individual's preparation and } \\
\text { participation, as these affect } \\
\text { overall } \\
\text { team performance. }\end{array}$ \\
\hline
\end{tabular}

environment that is competitive yet collaborative, where real-time feedback and guidance are assured. Such environments promote learner enthusiasm and creativity, critical thinking and deeper learning [3, 44], a hallmark of TBL. Furthermore, through teamwork and timely feedback from the instructor, TBL guards against entrenchment of misconceptions that all too often characterize didactic learning strategies. Additionally, repeated testing, using assignments centered around newly-learned concepts provides a powerful boost to knowledge retention. Here, TBL leverages on the most current evidence on learning theory - that knowledge retention is better with instructional strategies that involve repeated testing and not repeated study $[35,45,46]$.

With TBL, one can steer multiple teams concurrently without losing the benefit of instructor-guided small group learning models. In North America, experienced instructors have managed classes of up to 200 students
[47]. The ability to engage large classrooms in learning and consolidating new concepts should make TBL appealing to African medical schools that aspire to increase enrollment but are financially constrained, making it hard to correspondingly increase faculty $[24,31]$. Trials with the problem-based learning curriculum in Zimbabwe failed, in part, due to the high student-to-faculty ratio [13]. Similar challenges have been reported elsewhere [7, 48]. With TBL, schools can increase enrollment and yet deliver a student-centered active learning experience even with few faculty. Moreover, few but dedicated faculty stand a higher chance at negotiating better remuneration which would further boost faculty morale, productivity and learner satisfaction.

Unlike other group-based learning formats (e.g. CaseBased Learning and PBL), where educational resources (e.g. space, instructors, multimedia equipment etc.) are replicated for each group, TBL enables resource economization. 
For instance, multiple teams working within a single classroom can share space and equipment making substantial savings on scarce institutional resources. Furthermore, when instructors assume primary responsibility for sourcing study materials (notes, videos, research articles etc.), learners can focus on studying assigned material without losing quality time sifting through libraries or scouring the web. In Africa, such activities all too often occur within a backdrop of weak information systems infrastructure that only serves to frustrate learner experiences [14]. Thus, TBL ensures fair access to core study materials while reserving learners' prerogative to obtain additional information at convenience. Because students bear initial responsibility to read and comprehend new knowledge (pre-class preparation), TBL nurtures independent and life-long learning skills. This is more so because peers as well as the instructor, provide the cognitive support required for learner self-evaluation and improvement in study skills over time.

TBL provides a robust accountability model involving all parties to the learning process. Through the readiness assurance process, learners are accountable for attending class as well as preparing before they come. Peer evaluation (see Table 1) ensures that learners invest time and effort working within their teams. The instructor is accountable for initiating and guiding the learning process, providing cognitive support as learners work through the nuances akin to real-life decision-making. Team discussions involve peer tutoring, which leverage on learners' ability to use language (or examples) that peers easily relate with. It has been noted that even introverts develop the confidence to speak up, boosting their communication skills [49]. Moreover, intrateam dialogue taps into the diverse perspectives of learners - all of which inform and enrich problem-solving and foster critical thinking. With diverse perspectives, team members are bound to disagree, resulting in passionate rebuttals in defense of one's point of view. Thus, in addition to honing problem-solving and critical thinking skills, students develop the social skills necessary to harmoniously manage intellectual conflict. Furthermore, by working on the same problem and requiring teams to make specific choices (to be reported simultaneously), team cohesiveness and collaboration are fostered. The benefits of collaboration become evident when team scores turn up higher than the best individual scores on most occasions [50]. Bleakley and Brennan showed that curricula that use team learning strategies produce graduates who are not only competent in the "hard skills" but tend to outperform their peers in areas such as collaboration, tolerance of ambiguity and confidence in practice [51]. In addition, they showed that teamwork reduced the risk of medication errors resulting in better patient care [51]. These observations suggest that TBL learners gain insights into their own strengths and weaknesses, enabling them to negotiate and develop respectful and constructive working relationships.

\section{Challenges with initial implementation of TBL in a new setting}

As with all teaching methods applied to new physical or cultural environments, initial implementation of TBL comes with challenges. These challenges are, however, not unique to resource-constrained settings but may be more pronounced in settings that are not accustomed to change. For instance, context-specific factors such as differences in curriculum orientation or level of instructor autonomy within a course may limit instructors' freedom to experiment with TBL. In some cases, effective use of TBL will require redesigning entire courses. This can be quite challenging but achievable with gradual effort and determination [52]. Some content may require reorganization into major subunits in order to permit holistic discussion and real-life knowledge application on the subject matter. In pharmacology for instance, course topics under antibacterial chemotherapy may have to be merged and covered together without distinct sessions focused on different antibiotic categories. This creates the best platform to tackle assignments that closely model real-life situations e.g. why one antibiotic would be favored over another in managing an infant with bacterial pneumonia. Learners can meaningfully ponder on the different options using diverse arguments drawing on different aspects of the case such as pathophysiology, patient factors (e.g. age, immune status) or socialeconomic considerations and how they interplay with basic pharmacodynamic or pharmacokinetic principles. Likewise, in HIV pharmacotherapy, study materials covering its virology together with the basic and clinical science behind anti-retroviral therapies should be studied jointly in order to prepare learners for knowledge application assignments modeled on real-life challenges.

Developing appropriate knowledge application assignments is another challenge, since assignments should be relevant and captivating with ability to elicit the right learning experiences. Well-crafted assignments should model the challenges, nuances and ambiguities commonly encountered in practice, and not simply require solutions discoverable by re-examining prior assigned readings. Effective assignments should spur intellectual conflict, fostering deeper engagement with new knowledge through dialogue, interpretation, or extrapolation. Such assignments provoke probing questions and rebuttals during discussions, since each team is required to make (and later defend) a specific position lest they are embarrassed before the class. Only then can assignments evoke the vibrant discussions capable of yielding productive and enjoyable outcomes for all. Haidet and colleagues have used the term "constructive controversy" to 
sum up the characteristics of such assignments [41]. In contrast, simple and straightforward assignments may, at most, elicit intragroup dialogue, but risk stifling intergroup discussion as different teams will probably reach the same specific conclusion. Such assignments make TBL appear like any ordinary quiz session. Experts propose the use of the 'backward design' approach while developing appropriate assignments [53]. It is important that sufficient time (e.g. $50 \%$ of class-time) is devoted to knowledge-application (phase 3) as this ensures multiple opportunities for 'learning moments' that reinforce key concepts and contribute towards achieving course objectives [52].

The fact that each class begins with a test makes TBL stressful to some learners who may detest the anxiety associated with pre-class preparation. However, this is probably the most important phase in TBL as no amount of team discussion can compensate for lack of preparation, moreover, such ill-prepared members risk slowing team progress during problem-solving. Despite such stress, learning moments that result from discovering your own shortcomings during team discussions (or feedback) can be truly rewarding, making the pre-class effort worthwhile. Discovering one's own shortcomings helps learners hone skills such as critical appraisal, and the knowledge gained subsequently is better retained as studies show [46].

TBL ensures that individual and group effort are appropriately rewarded through judicious course assessment. Unlike other small group learning formats, low performers do not necessarily pull down the scores of high performers. This is achieved using a grading scheme in which each learners' final score (per session), is computed as an average between individual and group scores in the readiness assurance test. Each learner is thus held accountable for their own final score. Also, the closer learners work together, the better their team score, thus improving everyone's final score [54]. It is important to ensure that TBL scores count significantly towards final course grades as this provides additional impetus for adequate pre-class preparation, and subsequently, a vibrant class experience. Compared with lecture-based methods, there is evidence that academic performance with TBL is similar, if not better $[50,55]$. Nevertheless, the thrust of our case for TBL lies in its ability to nurture soft skills through cooperative learning implemented in a manner that is cost-effective for resource-poor settings. Due to increased popularity in recent times, TBL hybrids, where one or more of the aforementioned steps are omitted or modified, have been implemented and reported. While this may be justifiable for practical or context-specific reasons, it is important to note that such modifications can have significant effects on class outcomes as some of the underlying principles laid out in Table 1 may be eroded. For this reason, Haidet et.al. have argued for standardization of scholarly reports on TBL experiences [41]. Where such modifications have occurred, such standardized reporting would allow for more meaningful interpretation, comparisons, critiquing or replication of studies.

\section{Some early African experiences with team-based learning in medical education}

There have been few trials with TBL in Africa. One pilot was done in Zimbabwe between 2010 and 12, during a time when the declining economic situation imposed severe financial strain at the University of Zimbabwe, leading to a $69 \%$ vacancy rate at the College of Health Sciences [56]. Investigators implemented TBL to deliver two cycles of an HIV/AIDS module to 5th year medical students within a competency-based curriculum. At the end of each cycle, students completed a survey that assessed their experiences and perceived knowledge gain. All respondents agreed that TBL was an effective way to learn about HIV, with $66 \%$ strongly agreeing. The majority $(94 \%)$ felt TBL was more stimulating than lectures, while 91 and 94\% respectively, felt it fostered enthusiasm for course material and collaboration. Students perceived significant improvements in knowledge gained, particularly with challenging scenarios such as managing HIV drug resistance and treatment of HIV-TB co-infection. The authors concluded that TBL was feasible and offered a promising and exciting way of providing high-quality medical education at resource-limited institutions. In Tanzania, TBL was piloted with an ectoparasite module at Kilimanjaro Christian Medical University College in 2012 [57]. Here, investigators sought to explore perceptions as well as improvement in examination scores in comparison to the previous year, where a didactic approach was employed for the same course. For the 158 students surveyed, the mean score across six domains (content, learning process, knowledge, educational environment, assessment, instructors \& efficiency) ranged from 4.2-4.5 (5 being the most favorable). Using a strength of consensus measure, there was a high degree of consensus among learners (85-90\%). An improvement in examination scores was also noted, particularly among the lower $50 \%$. Elsewhere, such improved performance among the "at risk" group has been attributed to the strong social and academic support (through peer tutoring) embodied within TBL $[55,58,59]$. Overall, these studies attest to the applicability of TBL within the African context. We recently conducted a similar pilot at the University of Liberia's A.M. Dogliotti College of Medicine, which faces similar infrastructural and human resource challenges. Our initial experience with TBL will be reported elsewhere.

\section{Conclusion}

Since its initial use in the health sciences in 1999 [60], global interest in TBL has increased due to its ease of adoption as well as its consistency with current accreditation 
standards that seek to promote active learning strategies [25-28]. It is no wonder that world-wide, medical schools are increasingly adopting TBL as an instructional method in some shape or form for both preclinical and clinical education [40, 50]. As Africa strives to maintain its credibility in this highly dynamic field [16], TBL presents a resource-efficient avenue for imparting both hard and soft skills critical for effective clinical practice in the twentyfirst century. We therefore urge individual instructors as well as African medical schools at large, to experiment with TBL as a way to strengthen medical education in a manner that is responsive to human and institutional resource constraints.

\section{Abbreviations}

MEPI: Medical Education Partnership Initiative; PBL: Problem-Based Learning; TBL: Team-Based Learning

\section{Acknowledgements}

The authors are grateful for the advice and support received from Janet Hafler, Michael Schwartz, Pete Takizawa, and Nikole Allen.

\section{Authors' contributions}

COO and KTS jointly conceived this work. COO wrote the first draft and KTS made critical revisions to the draft. Both authors read and approved the final manuscript.

\section{Authors' information}

$\mathrm{COO}$ is a lecturer at the Department of Pharmacology, Faculty of Medicine, Gulu University in Uganda. He recently completed a one-year postdoc tenure with the Office of Global Health, Department of Internal Medicine, Yale School of Medicine. He was based in Monrovia where he taught and mentored preclinical students at the A.M. Dogliotti College of Medicine. KTS is assistant professor of General Internal Medicine at the Yale School of Medicine and core faculty member at the Equity Research and Innovation Center. She is also Lecturer at the Jackson Institute of Global Affairs and directs the Yale College Multidisciplinary Academic Program in Global Health.

\section{Funding}

COO and KTS received support from a World Bank grant to strengthen medical education in Liberia. KTS is also supported by funding from the U.S. Health Resources and Services Administration for Resilient and Responsive Health Systems in Liberia. The above institutions had no role in conception design or writing of this manuscript.

\section{Availability of data and materials}

Data sharing is not applicable to this article as no datasets were generated or analyzed during the current study.

\section{Ethics approval and consent to participate}

Not applicable

\section{Consent for publication}

Not applicable

\section{Competing interests}

The authors declare that they have no competing interests.

\section{Author details}

'Department of Pharmacology \& Therapeutics, Faculty of Medicine, Gulu University, P.O. Box 166, Gulu, Uganda. ${ }^{2}$ Department of Internal Medicine, Yale School of Medicine, P.O. Box 208364, New Haven, CT 06510, USA.
Received: 23 June 2019 Accepted: 18 October 2019

Published online: 04 November 2019

\section{References}

1. Jackson M, Calman K. Medical education past, present and future. Med Educ. 2006:40(3):190-2.

2. Papa FJ, Harasym PH. Medical curriculum reform in North America, 1765 to the present: a cognitive science perspective. Acad Med. 1999;74(2):154-64.

3. Kirschner PA, Sweller J, Clark RE. Why minimal quidance during instruction does not work: an analysis of the failure of constructivist, discovery, problembased, experiental, and inquiry-based teaching. Educ Psychol. 2006:41(2):75-86.

4. Schmidt HG. Assumptions underlying self-directed learning may be false. Med Educ. 2000:34(4):243-5.

5. Lim WK. Dysfunctional problem-based learning curricula: resolving the problem. BMC Med Educ. 2012:12:89.

6. Hamdy H. The fuzzy world of problem-based learning. Med Teach. 2008;30: 739-41.

7. Amoako-Sakyi D, Amonoo-Kuofi H. Problem-based learning in resource-poor settings: lessons from a medical school in Ghana. BMC Med Educ. 2015;15:221.

8. Kwan CY, Tam L. Commentary: hybrid PBL-what is in a name? J Med Educ. 2009;13:157-65.

9. Maudsley G. Do we all mean the same thing by 'problem-based learning'? A review of the concepts and a formulation of the ground rules. Acad Med. 1999:74:178-85.

10. Shanley PF. Leaving the "empty glass" of problem-based learning behind: new assumptions and a revised model for case study in preclinical medical education. Acad Med. 2007;82(5):S55-8.

11. Schmidt HG. Problem-based learning: does it prepare medical students to become better doctors? Med J Aust. 1998;168(9):429-30.

12. Berkson L. Problem-based learning: have the expectations been met? Acad Med. 1993;68(10 Suppl):S79-88,

13. Mufunda J, Chatora R, Ndambakuwa Y, Samkange C, Sigola L, Vengesa P. Challenges in training the ideal doctor for Africa: lessons learned from Zimbabwe. Med Teach. 2007;29(9):878-81

14. Chen C, Buch E, Wassermann T, Frehywot S, Mullan F, Omaswa F, et al. A survey of sub-Saharan African medical schools. Hum Resour Health. 2012;10:4.

15. Mengistu BS, Vins H, Kelly CM, McGee DR, Spicer JO, Derbew M, et al. Student and faculty perceptions on the rapid scale-up of medical students in Ethiopia. BMC Med Educ. 2017;17(1):11.

16. Gukas ID. Global paradigm shift in medical education: issues of concern for Africa. Med Teach. 2007;29(9):887-92.

17. Team-Based Learning: Small Group Learning's Next Big Step. New Directions in Teaching and Learning. Michaelsen LK, Sweet M, Parmalee DX. editors. Wiley; 2009

18. GBD 2017 Causes of Death Collaborators. Global, regional, and national agesex-specific mortality for 282 cuases of death in 195 countries and territories, 1980-2017: a systematic analysis of the Global Burden of Disease study 2017 Lancet. 2018;392:1736-88.

19. World Health Organization. Health workforce requirements for universal health coverage and the Sustainable Development Goals. Geneva, Switzerland. World Health Organization, 2016.

20. GBD 2017 Population and Fertility Collaborators. Populaton and fertility by age and sex for 195 countries and territories, 1950-2017: a systematic analysis for the Global Burden of Disease study 2017. Lancet. 2018;392:1995-2051.

21. United Nations Development Program. Human development indicators and Indicies 2018. New York: United Nations Development Program, Office HDR; 2018

22. World Health Organization. Report on the WHO/PEPFAR planning meeting on scaling up nursing and medical education. Geneva: World Health Organization; 2009.

23. Bokar Toure DAA, Jennifer Nyoni, Adam Ahmat. Road map for scaling up human resources for health for improved health service delivery in the African region 2012-2025. Afr Health Mon 2013(18).

24. Burdick W. Challenges and issues in health professions education in Africa. Med Teach. 2007:29(9):882-6.

25. Hendricson WD, Andrieu SC, Chadwick DG, Chmar JE, Cole JR, George MC, et al. Educational strategies associated with development of problem-solving, critical thinking, and self-directed learning. J Dent Educ. 2006;70(9):925-36.

26. Medical Council of India. Salient features of regulation on graduate medical education. 1997

27. Liaison Commettee on Medical Education. Functions and structure of a medical school. Standards for accrediatation of medical education programs leading to the M.D. degree 2012. 
28. World Federation For Medical Education. WFME global standards for quality improvement basic medical education Copenhagen. Denmark: World Federation For Medical Education; 2015.

29. General Medical Council. Tomorow's Doctors: Recommendation on Undergraduate Medical Education. London 2009

30. WHO Regional Office for Africa WFfME. Cape Town Declaration. Medical Education. 1995;29:385-6.

31. Mullan F, Frehywot S, Omaswa F, Buch E, Chen C, Greysen SR, et al. Medical schools in sub-Saharan Africa. Lancet. 2011;377(9771):1113-21.

32. Robertson LT. Memory and the brain. J Dent Educ. 2002;66(1):30-42.

33. Rolls ET. Memory systems in the brain. Annu Rev Psychol. 2000;51:599-630.

34. Friedlander MJ, Andrews L, Armstrong EG, Aschenbrenner C, Kass JS, Ogden P. What can medical education learn from the neurobiology of learning? Acad Med. 2011;86(4):415-20.

35. Augustin M. How to learn effectively in medical school: test yourself, learn actively, and repeat in intervals. Yale J Biol and Med. 2014;87:207-12.

36. Radcliffe $\mathrm{C}$, Lester $\mathrm{H}$. Perceived stress during undergraduate medical training: a qualitative study. Med Educ. 2003;37(1):32-8

37. Stewart $\mathrm{SM}$, Lam $\mathrm{TH}$, Betson $\mathrm{CL}$, Wong $\mathrm{CM}$, Wong AM. A prospective analysis of stress and academic performance in the first two years of medical school. Med Educ. 1999;33(4):243-50.

38. Kilmarx PH, Katz F, Razak MH, Palen J, Cheever LW. Glass RI. Strengthening Human Resources to End AIDS and Improve Health in Africa. Acad Med: The Medical Education Partnership Initiative; 2018.

39. Kiguli-Malwadde E, Talib ZM, Wohltjen H, Connors SC, Gandari J, Banda SS, et al. Medical education departments: a study of four medical schools in sub-Saharan Africa. BMC Med Educ. 2015;15:109.

40. Haidet P, Kubitz K, McCormack WT. Analysis of the team-based Learning literature: TBL comes of age. J Excel Coll Teach. 2014;25(3-4):303-33.

41. Haidet P, Levine RE, Parmelee DX, Crow S, Kennedy F, Kelly PA, et al. Perspective: guidelines for reporting team-based learning activities in the medical and health sciences education literature. Acad Med. 2012; 87(3):292-9.

42. Johnson DW, Johnson RT, Tjosvold D. Constructive controversy: the value of intellectual opposition. In: Deutsch M, Coleman PT, editors. The handbook of conflict resolution: theory and practice. San Francisco: Jossey-Bas Publishers; 2000. p. 65-85.

43. Ellis AP, Hollenbeck JR, Ilgen DR, Porter CO, West BJ, Moon H. Team learning: collectively connecting the dots. J Appl Psychol. 2003;88(5):821-35.

44. Kelly PA, Haidet P, Schneider V, Searle N, Seidel CL, Richards BF. A comparison of in-class learner engagement across lecture, problem-based learning, and team learning using the STROBE classroom observation tool. Teach Learn Med. 2005;17(2):112-8.

45. Larsen DP, Butler AC, Roediger HL 3rd. Test-enhanced learning in medical education. Med Educ. 2008:42(10):959-66.

46. Larsen DP, Butler AC, Roediger HL 3rd. Repeated testing improves longterm retention relative to repeated study: a randomised controlled trial. Med Educ. 2009;43(12):1174-81.

47. Searle NS, Haidet P, Kelly PA, Schneider VF, Seidel CL, Richards BF. Team learning in medical education: initial experiences at ten institutions. Acad Med. 2003;78(10 Suppl):S55-8.

48. Carrera LI, Tellez TE, D'Ottavio AE. Implementing a problem-based learning curriculum in an Argentinean medical school: implications for developing countries. Acad Med. 2003;78(8):798-801.

49. Hazel SJ, Heberle N, McEwen MM, Adams K. Team-based learning increases active engagement and enhances development of teamwork and communication skills in a first-year course for veterinary and animal science undergraduates. J Vet Med Educ. 2013;40(4):333-41.

50. Searle N, Haidet P, Kelly PA, Schneider VF, Seidel CL, Richards BF. Team learning in medical education: experiences at ten insittutions. Acad Med. 2003;78(10):S55-S8.

51. Bleakley A, Brennan N. Does undergraduate curriculum design make a difference to readiness to practice as a junior doctor? Med Teach. 2011; 35:459-67.

52. Parmelee D, Michaelsen LK, Cook S, Hudes PD. Team-based learning: a practical guide: AMEE guide no. 65. Med Teach. 2012;34:e275-e87.

53. Parmelee DX, Michaelsen LK. Twelve tips for doing effective team-based Learning (TBL). Med Teach. 2010;32(2):118-22.

54. Fink LD. Beyond small groups: Harnessing the extraoridinary power of learning in teams. Michaelsen LK, Knight $A B$, Fink LD, editors VA: Sterling; 2004.
55. Letassy N, Medina M, Stroup J, Fugate S, Britton M. The impact of teambased learning (TBL) on student and course outcomes compared to lecture methods. Annual Meeting of the American Association of Colleges of Pharmacy; Disney's Yatch \& Beach Club Resort, Lake Buena Vista. 2007.

56. Gray J, Fana GT, Campbell TB, Hakim JG, Borok MZ, Aagaard EM. Feasibility and sustainability of an interactive team-based learning method for medical education during a severe faculty shortage in Zimbabwe. BMC Med Educ. 2014;14:63.

57. Nyindo M, Kitau J, Lisasi E, Kapanda G, Matowo J, Francis P, et al. Introduction of team-based learning (TBL) at Kilimanjaro Christian Medical University college: experience with the ectoparasites module. Med Teach. 2014;36(4):308-13.

58. Nieder GL, Parmelee DX, Stolfi A, Hudes PD. Team-based learning in a medical gross anatomy and embryology course. Clin Anat. 2005;18(1):56-63.

59. Touchet BK, Coon KA. A pilot use of team-based learning in psychiatry resident psychodynamic psychotherapy education. Acad Psych. 2005;29:293-6.

60. Seidel CL, Richards BF. Application of team learning in a medical physiology course. Acad Med. 2001;76:533-4.

\section{Publisher's Note}

Springer Nature remains neutral with regard to jurisdictional claims in published maps and institutional affiliations.

Ready to submit your research? Choose BMC and benefit from:

- fast, convenient online submission

- thorough peer review by experienced researchers in your field

- rapid publication on acceptance

- support for research data, including large and complex data types

- gold Open Access which fosters wider collaboration and increased citations

- maximum visibility for your research: over $100 \mathrm{M}$ website views per year

At BMC, research is always in progress.

Learn more biomedcentral.com/submissions 